\title{
T cells bearing anti-CD19 and/or anti-CD38 chimeric antigen receptors effectively abrogate primary double-hit lymphoma cells
}

Keichiro Mihara ${ }^{1 *}$, Tetsumi Yoshida ${ }^{1}$, Yoshifumi Takei ${ }^{2}$, Naomi Sasaki ${ }^{3}$, Yoshihiro Takihara $^{4}$, Junya Kuroda ${ }^{5}$ and Tatsuo Ichinohe ${ }^{1}$

\begin{abstract}
Patients with $B$ cell lymphomas bearing MYC translocation combined with translocation involving other genes, such as $B C L 2, B C L 3$, or $B C L 6$, defined as double-hit lymphoma ( $\mathrm{DHL}$ ), have a poor prognosis. Recent studies expanded the concept to include double-expressing lymphoma (DEL) that co-overexpresses MYC protein with either of those proteins. Accordingly, we defined cytogenetic DHL and DEL as primary DHL. An adoptive T cell immunotherapy with a chimeric antigen receptor (CAR) has been clinically shown to exhibit cytotoxicity in refractory neoplasias. We revealed the marked cytotoxicity of anti-CD19- and/or anti-CD38-CAR T cells against primary DHL cells from patients. CD19- and/or CD38-specific T cells were co-cultured with cytogenetic DHL $(n=3)$ or DEL $(n=2)$ cells from five patients for 3 days. We examined whether $T$ cells retrovirally transduced with each vector showed cytotoxicity against DHL cells. Anti-CD19- and/or anti-CD38-CAR T cells were co-cultured with primary DHL cells at an E:T ratio of 1:2 for 3 days. Anti-CD19- and anti-CD38-CAR T cells completely abrogated these DHL cells, respectively. Anti-CD19-CAR T cells synergistically exerted collaborative cytotoxicity against these primary DHL cells with anti-CD38-CAR T cells. Therefore, refractory DHL cells can be efficiently abrogated by the clinical use of $T$ cells with anti-CD19- and/or anti-CD38-CAR.
\end{abstract}

Keywords: T cell immunotherapy, Double-hit lymphoma, Double-expressing lymphoma, Chimeric antigen receptor (CAR), Anti-CD19-CAR, Anti-CD38-CAR

\section{Letter to the Editor}

Patients with B cell lymphoma bearing $M Y C$ translocation combined with an additional translocation involving other genes, such as $B C L 2, B C L 3, B C L 6$, or CCND1, whose category is defined as double-hit lymphoma (DHL), have a dismal prognosis [1]. Li et al. reported that the prognosis of $\mathrm{B}$ cell lymphoma patients expressing concurrent MYC and BCL2 proteins without translocations was also dismal as well as that of DHL-bearing translocations of $M Y C / B C L 2$ genes in terms of the prognosis [1-4]. Thus, recent studies have expanded the

\footnotetext{
* Correspondence: kmmihara@hiroshima-u.ac.jp

${ }^{1}$ Department of Hematology and Oncology, Research Institute for Radiation Biology and Medicine, Hiroshima University, 1-2-3 Kasumi, Minami-ku, Hiroshima 734-8553, Japan

Full list of author information is available at the end of the article
}

concept to include double-expressing lymphoma (DEL) that co-overexpresses MYC protein with those proteins. Accordingly, we defined cytogenetic DHL and DEL as primary DHL. An adoptive T cell immunotherapy with anti-CD19 chimeric antigen receptors (CAR) has been clinically shown to exhibit marked cytotoxicity in patients with relapsed and refractory B cell lymphoid neoplasias [5-7]. We also developed anti-CD38-CAR and demonstrated its marked cytotoxicity against various hematological malignancies $[8,9]$. However, it has not been elucidated whether CAR therapy could be effective for patients with cytogenetic DHL and DEL. Here, we revealed the marked cytotoxicity of anti-CD19- and/or anti-CD38-CAR $\mathrm{T}$ cells as well as the synergy of both CARs against primary DHL cells. 
Cytogenetic DHL $(n=3)$ or DEL $(n=2)$ cells of the lymph nodes were collected from five patients (Table 1) after obtaining appropriate informed consent. CD19 ${ }^{+}$ CD20 ${ }^{+}$lymphoma cells accounted for over 90\% (90-97\%). DHL (DEL) cell line cells, bearing the translocation of the I $g H / M Y C$ gene as well as overexpression of BCL2 protein (KPUM-UH1) or these primary cells were cultured in RPMI-1640 complete medium.

The cutoffs for immunohistochemical positivity for BCL2, BCL6, and MYC (Abcam, Cambridge, MA, USA) were 50,30 , and $40 \%$ of microscopically observed lymphoma cells, respectively. FISH analyses were performed by SRL (Tokyo, Japan).

The retroviral vector of anti-CD19- and anti-CD38CAR was previously developed [8-10]. To produce a RD114-pseudotyped retrovirus, MSCV-IRES-EGFP-antiCD19-CAR or MSCV-IRES-EGFP-anti-CD38-CAR, pEQPAM3(-E), and pRDF were used to co-transfect 293T cells with Lipofectamine plus (Invitrogen, Carlsbad, CA, USA). Peripheral blood mononuclear cells of donors were cultured for $48 \mathrm{~h}$ with $7 \mu \mathrm{g} / \mathrm{ml}$ PHA-M (Sigma, St Louis, MO, USA), $200 \mathrm{IU} / \mathrm{ml}$ interleukin-2 (PeproTech, London, UK) in the complete medium as described previously [8-10]. These $\mathrm{T}$ cells were retrovirally transduced in the presence of $4 \mu \mathrm{g} / \mathrm{ml}$ polybrene (Sigma) in a retronectin-coated tube (Takara-Bio, Otsu, Japan). For the transduction of anti-CD38-CAR, an anti-CD38 antibody (CPK-H; MBL, Nagoya, Japan) was added to the culture medium to protect transduced $\mathrm{T}$ cells from autolysis through cross-linkage of the antiCD38-CAR with intrinsic CD38 [8,9]. For the subsequent co-culture experiments, transduced $\mathrm{T}$ cells expressing green fluorescent protein (GFP) were sorted by FACSAria (BD). The specimens from patients and donors were used after approval by the institutional review board of Hiroshima University.

Primary DHL cells co-cultured with anti-CD19- and/ or anti-CD38-CAR T cells were harvested and stained with an anti-CD19 antibody-PE and anti-CD38 antibodyAPC (BD). These cells were then analyzed by a flow cytometer. Specific cytotoxicity of anti-CD19- and/or antiCD38-CAR T cells against $\mathrm{CD} 19^{+}$primary DHL cells was evaluated using the formula $(\mathrm{B}-\mathrm{A}) / \mathrm{B}$, where $\mathrm{A}$ is the number of $\mathrm{CD}_{19}{ }^{+} \mathrm{GFP}^{-}$cells or $\mathrm{CD}^{+} 8^{+} \mathrm{GFP}^{-}$cells after incubation with anti-CD19- or anti-CD38-CAR-expressing $\mathrm{T}$ cells, respectively, and $\mathrm{B}$ is the number of $\mathrm{CD} 19^{+} \mathrm{GFP}^{-}$or $\mathrm{CD}^{2} 8^{+} \mathrm{GFP}^{-}$cells after incubation with vector-transduced T cells [8-10].

We initially detected cytogenetic DHL and DEL (Additional file 1: Figure S1 and Table 1). Next, we confirmed that goat anti-mouse-IgG-PerCP, which cross-reacts with CAR and GFP of the vector, were co-expressed as an internal control in $\mathrm{T}$ cells retrovirally transduced (transduction efficiency: $67.42 \pm 14.43 \%(n=5)$ for anti-CD19-CAR, $63.21 \pm 10.89 \%(n=5)$ for anti-CD38-CAR).

Prior to co-culture experiments, we examined whether CD $19^{+}$primary DHL cells expressed CD38. We showed that $>97 \%$ of DHL cells obtained from five patients expressed CD38 (Table 1). DHL (DEL) cell line cells (KPUM-UH1) expressing CD19 and CD38 were cocultured with anti-CD19- or anti-CD38-CAR T cells at an effector $(\mathrm{E})$ target $(\mathrm{T})$ ratio of 1:2 for 3 days. Coculture experiments showed that either anti-CD19- or anti-CD38-CAR $\mathrm{T}$ cells almost completely eradicated KPUM-UH1 cells (Fig. 1a). As further experiments, CD19- or CD38-specific T cells were co-cultured with cytogenetic DHL $(n=3)$ or DEL $(n=2)$ cells from five patients at an E:T ratio of 1:2 for 3 days. Similarly, anti-

Table 1 Patients' profiles and cytotoxicity of T cells expressing anti-CD19- or anti-CD38-CAR against primary DHL cells

\begin{tabular}{|c|c|c|c|c|c|c|}
\hline Cells & Karyotype (major abnormalities) & IHC-positive & FISH-positive & $\begin{array}{l}{ }^{\mathrm{a}} \text { Expression of } \\
\text { CD38 in CD19+ } \\
\text { cells (\%) }\end{array}$ & $\begin{array}{l}\text { aSpecific cytotoxicity } \\
\text { of anti-CD19-CAR } \\
\text { T cells (\%) }\end{array}$ & 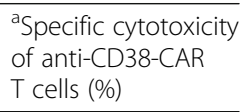 \\
\hline Patient 1 & $\mathrm{t}(8 ; 22)(\mathrm{q} 24 ; \mathrm{q} 11.2), \mathrm{t}(14 ; 18)(\mathrm{q} 32 ; \mathrm{q} 21)$ & $\begin{array}{l}\text { BCL2 } \\
\text { MYC: ND }\end{array}$ & BCL2 MYC & $98.69 \pm 0.37$ & $92.67 \pm 0.55$ & $97.49 \pm 0.19$ \\
\hline Patient 2 & $\operatorname{add}(8)(q 24), t(8 ; 14)(q 24 ; q 32), t(3 ; 22)(q 27 ; q 11.2)$ & $\begin{array}{l}\text { BCL2 } \\
\text { BCL6 } \\
\text { MYC }\end{array}$ & $\begin{array}{l}\text { BCL6 } \\
\text { MYC }\end{array}$ & $98.74 \pm 0.59$ & $95.53 \pm 2.88$ & $99.88 \pm 0.73$ \\
\hline Patient 3 & ND & $\begin{array}{l}\text { BCL2 } \\
\text { BCL6 } \\
\text { MYC }\end{array}$ & BCL6 & $97.37 \pm 0.02$ & $98.94 \pm 0.03$ & $99.60 \pm 0.27$ \\
\hline Patient 4 & ND & $\begin{array}{l}\text { BCL2 } \\
\text { MYC: ND }\end{array}$ & $\begin{array}{l}\text { BCL2 } \\
\text { MYC }\end{array}$ & $98.47 \pm 0.26$ & $98.26 \pm 0.78$ & $99.47 \pm 0.04$ \\
\hline Patient 5 & $+8, \operatorname{add}(3)(\mathrm{q} 27)$ & $\begin{array}{l}\text { BCL2 } \\
\text { BCL6 } \\
\text { MYC }\end{array}$ & BCL6 & $97.14 \pm 0.83$ & $97.41 \pm 0.16$ & $97.70 \pm 0.23$ \\
\hline
\end{tabular}

Specific cytotoxicity was evaluated by flow cytometry following the co-incubation of $T$ cells bearing anti-CD19- or anti-CD38-CAR (E) with DHL cells ( $\mathrm{T}$ ) at an E:T ratio of $1: 2$ for 3 days. The cutoffs for positivity for BCL2, BCL6, or MYC were 50, 30, and $40 \%$ of the cells, respectively ND not determined

${ }^{\mathrm{a}}$ Results are the mean \pm SD of three experiments 


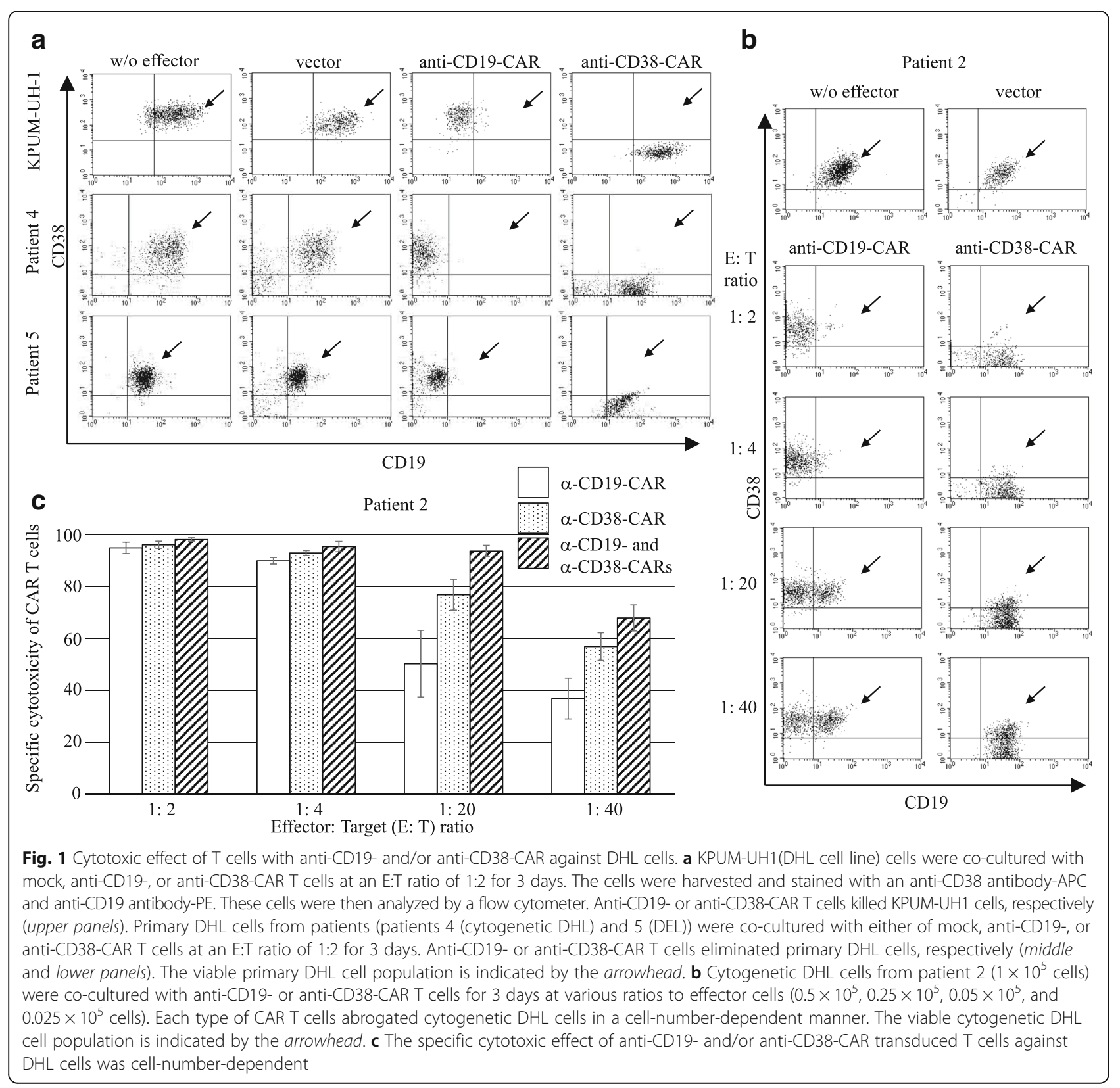

CD19- or anti-CD38-CAR T cells completely abolished the primary DHL cells, respectively (Fig. 1a, c and Table 1). Using DHL cells from patient 2, we confirmed that each of the CAR T cells eliminated DHL cells in a cell-number-dependent manner (Fig. 1b, c). Additionally, anti-CD19-CAR $\mathrm{T}$ cells synergistically exerted a collaborative cytotoxicity against DHL cells from patient 2 with anti-CD38-CAR T cells, as shown in Fig. 1c. The simultaneous combination index was less than 1.0, leading to the synergy according to Calcusyn software (Biosoft, Cambridge, UK).

These results showed that primary DHL cells, which are refractory or resistant to existing chemotherapeutic agents, can be efficiently abrogated by the clinical use of $\mathrm{T}$ cells with anti-CD19- and/or anti-CD38-CAR. Taken together, these results may warrant adoptive immunotherapy with $\mathrm{T}$ cells transduced with anti-CD19- and/or anti-CD38-CAR for patients with refractory cytogenetic DHL and DEL.

\section{Additional files}

Additional file 1: Figure S1. Morphology of cells in the specimens on hematoxylin-eosin staining is shown. MYC expression is shown in lymph node specimens from patient 3. LPF, MPF, and HPF denote low-power, middle-power, and high-power fields, respectively. (PPTX 1063 kb) 


\section{Abbreviations}

CAR: Chimeric antigen receptor; DEL: Double-expressing lymphoma; DHL: Doublehit lymphoma; GFP: Green fluorescent protein; PerCP: Peridinin chlorophyll protein complex

\section{Acknowledgements}

We thank Sachiko Fukumoto and Ryoko Matsumoto (Department of Hematology and Oncology, Hiroshima University) for providing us with experimental assistance.

\section{Funding}

This study was supported in part by grants from the Ministry of Health, Labour, and Welfare of Japan.

\section{Availability of data and materials}

The datasets used and/or analyzed during the current study are available from the corresponding author on reasonable request.

\section{Authors' contributions}

KM designed and performed the experiments, analyzed the data, and wrote the paper. JK provided us with KPUM-UH1 cells and comments on writing the paper. TY and YT analyzed the data. YT, NS, and TI helped write the manuscript. All authors contributed to the interpretation of the results. All authors read and approved the final manuscript.

\section{Competing interests}

The authors declare that they have no competing interests.

\section{Consent for publication}

Not applicable.

\section{Ethics approval and consent to participate}

The specimens from the patients and donors were used after obtaining appropriate informed consent and approval by the institutional review board of Hiroshima University.

\section{Publisher's Note}

Springer Nature remains neutral with regard to jurisdictional claims in published maps and institutional affiliations.

\section{Author details}

${ }^{1}$ Department of Hematology and Oncology, Research Institute for Radiation Biology and Medicine, Hiroshima University, 1-2-3 Kasumi, Minami-ku, Hiroshima 734-8553, Japan. ²Department of Medicinal Biochemistry, School of Pharmacy, Aichi Gakuin University, Nagoya 470-0195, Japan. ${ }^{3}$ Department of Pathology, Kure Kyosai Hospital, Kure 737-0811, Japan. ${ }^{4}$ Department of Stem Cell Biology, Research Institute for Radiation Biology and Medicine, Hiroshima University, Hiroshima 734-8553, Japan. ${ }^{5}$ Division of Hematology and Oncology, Kyoto Prefectural University of Medicine, Kyoto 602-8566, Japan.

Received: 18 April 2017 Accepted: 2 June 2017

Published online: 08 June 2017

\section{References}

1. Cheah CY, Oki Y, Westin JR, Turturro F. A clinician's guide to double hit lymphomas. Br J Haematol. 2015;168(6):784-95.

2. Friedberg JW. Double-hit diffuse large B-cell lymphoma. J Clin Oncol. 2012;30(28):3439-43

3. Li S, Lin P, Fayad LE, Lennon PA, Miranda RN, Yin CC, Lin E, Medeiros $\sqcup$. B-cell lymphomas with MYC/8q24 rearrangements and IGH@BCL2/ $t(14 ; 18)(q 32 ; q 21)$ : an aggressive disease with heterogeneous histology, germinal center B-cell immunophenotype and poor outcome. Mod Pathol. 2012;25(1):145-56.

4. Perry AM, Alvarado-Bernal Y, Laurini JA, Smith LM, Slack GW, Tan KL, Sehn LH, Fu K, Aoun P, Greiner TC, Chan WC, Bierman PJ, Bociek RG, Armitage JO, Vose JM, Gascoyne RD, Weisenburger DD. MYC and BCL2 protein expression predicts survival in patients with diffuse large B-cell lymphoma treated with rituximab. Br J Haematol. 2014;165(3):382-91.
5. Park JH, Geyer MB, Brentjens RJ. CD19-targeted CAR T-cell therapeutics for hematologic malignancies: interpreting clinical outcomes to date. Blood. 2016;127(26):3312-20.

6. Davila ML, Sadelain M. Biology and clinical application of CAR T cells for B cell malignancies. Int J Hematol. 2016;104(1):6-17.

7. Maude S, Barrett DM. Current status of chimeric antigen receptor therapy for haematological malignancies. Br J Haematol. 2016;172(1):11-22.

8. Mihara K, Yanagihara K, Takigahira M, Imai C, Kitanaka A, Takihara Y, Kimura A. Activated T-cell-mediated immunotherapy with a chimeric receptor against CD38 in B-cell non-Hodgkin lymphoma. J Immunother. 2009:32(7):737-43.

9. Mihara K, Bhattacharyya J, Kitanaka A, Yanagihara K, Kubo T, Takei Y, Asaoku H, Takihara Y, Kimura A. T-cell immunotherapy with a chimeric receptor against CD38 is effective in eliminating myeloma cells. Leukemia. 2012;26(2):365-7.

10. Imai C, Mihara K, Andreansky M, Nicholson IC, Pui CH, Geiger TL, Campana D. Chimeric receptors with 4-1BB signaling capacity provoke potent cytotoxicity against acute lymphoblastic leukemia. Leukemia. 2004;18(4):676-84.

\section{Submit your next manuscript to BioMed Central and we will help you at every step:}

- We accept pre-submission inquiries

- Our selector tool helps you to find the most relevant journal

- We provide round the clock customer support

- Convenient online submission

- Thorough peer review

- Inclusion in PubMed and all major indexing services

- Maximum visibility for your research

Submit your manuscript at www.biomedcentral.com/submit
) Biomed Central 